\title{
Practical Problems of Delimitation of Real Estate under the Provisions of the Water Law**
}

\section{Introduction}

Land covered by water is a special type of object entered into the register of land and buildings. It is a separate usable land which includes: land under the internal marine waters $(\mathrm{Wm})$, land under surface flowing waters $(\mathrm{Wp})$ and land under surface still waters (Ws). These types of usable land do not constitute an exhaustive list of all the areas covered by water. Land under ponds (Wsr) and land under ditches (W) are registered as agricultural land as well.

The amended Regulation on the register of land and buildings [7] assumes that the modernization of the records will be carried out in a planned manner, ensuring the creation of a computer database of the records by 31 December 2014 for urban areas and 31 December 2016 for rural areas. It will also relate to the land under waters. Pursuant to section 3a, added on 31 December 2013 to $\S 9$ of the Regulation "the land occupied by a natural watercourse is a separate cadastral parcel within the boundaries of the shoreline, regardless of whether the water in this watercourse flows in a natural bed or in a regulated bed, open or covered". At the same time, the added $\S 82$ a says that "pending the determination of the shoreline of natural watercourses, lakes and other natural reservoirs, based on the principles laid down in the provisions of the Act - Water Law, the course of the boundary between the land forming the bottoms and banks or shores of these watercourses, lakes or reservoirs and the land adjacent to them, is presented in the records using the data based on the results of field detailed measurements, performed in such a way that the identification of the course of the boundary was made in accordance with the provisions of article 15 sections 1, 5 and 6 of the Act of 18 July 2001 - the Water Law". Ultimately, all of the boundaries of land covered by water, in accordance with the quoted $\S 82 \mathrm{a}$

* AGH University of Science and Technology, Faculty of Mining Surveying and Environmental Engineering, Krakow, Poland

** The study has been carried out with financial support from the statutory research no. 11.11.150.005 AGH University of Science and Technology 
of the Regulation, should have determined boundaries under the provisions of the Water Law [12].

According to the Act - Water Law [12], waters may be divided into groundwaters and surface ones. The latter include marine waters (waters of the territorial sea and internal marine waters) as well as inland waters. The inland surface waters are divided into the flowing and still waters. The Water Law provides for a specific procedure for adjusting boundaries between the land under waters and the adjacent land, which is different from the procedures regulated by the Geodetic and Cartographic Law. However, in practice, the implementation of this procedure encounters numerous problems due to the imprecise regulations, which is reflected in the literature [1-4, 13].

This article analyzes the existing provisions of law on determining the boundaries of land under inland waters. Based on the author's own experiments and available studies, the practical problems in the implementation of this procedure were emphasized. It was proposed to complement the Regulation so as to indicate clearly the successive stages of the proceedings and the persons responsible for their implementation.

\section{Entities Who Are the Owners and Those Exercising Ownership Rights to Waters}

The waters are a special land property. They are not a separate object within the meaning of the Civil Code [10], but they are part of real estate. Pursuant to article 14 section 1 of the Water Act, the land covered by surface waters is the property of the owner of these waters. The Water Law allows for the ownership rights to the water to be exercised by the State Treasury, legal persons or natural persons. However, not all types of waters are treated equally, because under article 10 section $1 \mathrm{a}$, the waters of the territorial sea, internal marine waters including internal marine waters of the Gulf of Gdansk, inland surface flowing waters and groundwaters are solely the property of the State Treasury.

Ownership rights to public waters owned by the State Treasury will be exercised by the entities presented in Table 1.

Land covered by surface flowing waters, owned by the State Treasury, is the real estate resource of the Treasury, to which the provisions of the Act of 21 August 1997 on the real estate management do not apply. Accepting the land covered by surface flowing waters into the resource and its removal from the resource is determined by way of a decision, at the request of the competent authority or body exercising ownership rights to the waters, by the competent governor pursuing the task of the government administration. The land is not subject to any civil law transactions. 
Table 1. Entities exercising ownership rights to the waters owned by the State Treasury

\begin{tabular}{|c|c|}
\hline $\begin{array}{l}\text { Entity exercising ownership rights to the waters } \\
\text { owned by the State Treasury }\end{array}$ & Type of the waters \\
\hline The minister responsible for maritime affairs. & $\begin{array}{l}\text { The waters of the territorial sea, internal marine } \\
\text { waters and the waters of the Gulf of Gdansk. }\end{array}$ \\
\hline $\begin{array}{l}\text { President of the National Water Management } \\
\text { Board }\end{array}$ & $\begin{array}{l}\text { The waters essential for the development of } \\
\text { water resources and flood protection, especially } \\
\text { groundwaters and inland surface waters: } \\
\text { a) in mountain streams and their sources, } \\
\text { b) in natural watercourses, from the sources to } \\
\text { the estuary, with an average flow of several years } \\
\text { equal to, or higher than, } 2.0 \mathrm{~m}^{3} / \mathrm{s} \text { at the estuary } \\
\text { section, } \\
\text { c) in lakes and artificial reservoirs crossed by } \\
\text { watercourses referred to in clause b, } \\
\text { d) boundary waters, } \\
\text { e) in inland waterways }\end{array}$ \\
\hline Director of the national park & $\begin{array}{l}\text { The waters within the national park territory, with } \\
\text { the exception of the boundary waters and inland } \\
\text { waterways, which are classified in a class higher } \\
\text { than class I, on the basis of the Act of } 21 \text { December } \\
2000 \text { on the inland waterway }\end{array}$ \\
\hline $\begin{array}{l}\text { Marshal of the province, as a task of the } \\
\text { government administration carried out by the } \\
\text { provincial government }\end{array}$ & $\begin{array}{l}\text { The waters essential for the regulation of } \\
\text { hydrographic conditions for agriculture, aimed at } \\
\text { improving the productive capacity of the soil and } \\
\text { facilitating its cultivation, and in relation to other } \\
\text { waters not listed above }\end{array}$ \\
\hline $\begin{array}{l}\text { Forest manager, by way of an agreement } \\
\text { concluded at their request with the President of } \\
\text { the National Water Management Board or the } \\
\text { Marshal of the province, with the consent of the } \\
\text { Minister responsible for water management }\end{array}$ & $\begin{array}{l}\text { The waters, in relation to which the ownership } \\
\text { rights are exercised by the President of the } \\
\text { National Water Management Board or Marshal of } \\
\text { the province, except for the boundary waters }\end{array}$ \\
\hline $\begin{array}{l}\text { Entities representing the State Treasury under } \\
\text { separate regulations }\end{array}$ & $\begin{array}{l}\text { Still waters, and the waters in ditches located on } \\
\text { real estate owned by the State Treasury }\end{array}$ \\
\hline
\end{tabular}

Source: own study based on the Water Act [12]

If inland surface flowing water or water of the territorial sea or internal marine waters occupy permanently, in a natural way, the land which not in the ownership of the owner of the water, the land becomes the property of the owner of the water, i.e. the State Treasury. In this situation, the former owner of the land is entitled to compensation. In contrast, islands and alluvium which have been formed in a natural way on the land covered by surface waters are the property of the owner of the land. In a situation where, as a result of the natural action of water, an area which is not covered by water is created, this area remains the property of the current owner of the water. And so, islands and alluvium which have been formed in a natural way 
on the land covered by surface waters are the property of the owner of the land. Oxbow lakes and the land resulting from the implementation of regulatory structures remain the property of the current owner of the water. The land created as a result of permanent, natural or artificial deposition on the areas of the territorial sea waters or internal marine waters, remains the property of the State Treasury. It is, however, no longer the area of water and can be traded subject to the conditions laid down in the Act on real estate management.

\section{Determining the Real Estate Boundary Covered by Surface Waters}

\subsection{Definition of Land Covered by Water}

From the point of view of determining the boundaries between the land covered by water and the adjacent land, the definition of inland waters is essential. Pursuant to article 14 section 1a, which entered into force on 29 July 2005, the land covered by inland surface waters and internal marine waters is understood as the land forming the bottoms and banks of natural water courses, lakes and other natural reservoirs, within the boundaries of the shoreline, as well as the land belonging to the artificial reservoirs, barrages and dammed up lakes, which are the land covered by surface waters prior to the damming.

According to Kowalski [2], the legislature narrowed the definition of inland waters in 2005 in relation to the definition contained in article 5 section 3 of this Act, under which inland surface waters are divided into:

- flowing waters, which include the water:

- in natural watercourses, canals, and the sources where streams originate,

- in lakes and other natural bodies of water with a continuous or periodic natural inflow or outflow of surface waters,

- in artificial reservoirs located on the flowing waters;

- still waters, which include the water found in lakes and other natural reservoirs, which are not connected directly, in a natural way, with surface flowing waters.

According to Kowalski [2], this second definition should be treated in terms of natural phenomena, rather than legislature. The legislature clarified the concept of surface waters by limiting them spatially to the form of a shoreline and excluding the land covered by water as a result of a human activity.

Assuming that reasoning, Kowalski and Majewska in their publication of 2010 [3] pointed out the differences in definition of the land covered by surface flowing waters contained in the Act - Water Law, and in the Regulation on the register of land and buildings. The authors demonstrated that the Register of land and buildings defines flowing waters based on the factual circumstances, without the requirement to 
take into account natural shapes of watercourses. The issue is important due to the fact that not all the flowing waters are the property of the State Treasury. Therefore, these discrepancies may cause indications of the flowing water contour in the cadstral records different from ownership rights of the State Treasury.

On 31 December 2013, a substantial amendment to the regulation on the Register of land and buildings entered into force. It also changed the definitions of the land under waters by referring directly to the Water Act, but to article 5 section 3 (Tab. 2), rather than article 14 section 1 a.

Table 2. The definitions contained in the Regulation on the register of land and buildings

\begin{tabular}{|c|c|c|}
\hline Type of land & Definition in force until 30.12.2013 & Definition in force since 31.12.2013 \\
\hline $\begin{array}{l}\text { Land under } \\
\text { surface flowing } \\
\text { waters - Wp }\end{array}$ & $\begin{array}{l}\text { The land under surface flowing waters } \\
\text { includes the land under the waters } \\
\text { flowing in rivers, mountain streams, } \\
\text { canals and other watercourses, of } \\
\text { permanent or seasonal flows, as well as } \\
\text { the sources which the streams originate } \\
\text { from, and also the land under the } \\
\text { waters located in lakes and artificial } \\
\text { reservoirs, which the watercourses } \\
\text { flow from, or which they flow into }\end{array}$ & $\begin{array}{l}\text { The land under surface flowing waters } \\
\text { includes the land covered by surface } \\
\text { flowing waters referred to in article } 5 \\
\text { section } 3 \text { clause } 1 \text { of the Act of } 18 \text { July } \\
2001 \text { - the Water Law. } \\
\text { The contour of the land under the surface } \\
\text { flowing waters is determined by the banks } \\
\text { of the natural watercourses, shores of the } \\
\text { lakes and other natural reservoirs, and in } \\
\text { the case of canals or artificial reservoirs } \\
\text { situated on the flowing waters - the outer } \\
\text { edges of these canals or reservoirs. } \\
\text { If any natural watercourse, lake, or other } \\
\text { natural or artificial reservoir, or a canal } \\
\text { crosses the boundary of the cadastral unit, } \\
\text { then its boundary shall limit the contour of } \\
\text { the land under the waters }\end{array}$ \\
\hline $\begin{array}{l}\text { Land under } \\
\text { surface still } \\
\text { waters - Ws }\end{array}$ & $\begin{array}{l}\text { The land under surface still waters } \\
\text { includes the land under the waters in } \\
\text { lakes and reservoirs other than the land } \\
\text { defined as the land under the internal } \\
\text { marine waters and the land under } \\
\text { surface flowing waters }\end{array}$ & $\begin{array}{l}\text { The land under surface still waters includes } \\
\text { the land covered by surface still waters } \\
\text { referred to in article } 5 \text { section } 3 \text { clause } 2 \text { of } \\
\text { the Act of } 18 \text { July } 2001 \text { - the Water Law, as } \\
\text { well as the land permanently covered by } \\
\text { water located in hollows resulting from } \\
\text { the human activities, other than ponds and } \\
\text { not included in the wasteland. The contour } \\
\text { of the land under the surface still waters } \\
\text { is determined by the banks of the natural } \\
\text { reservoirs, and in the case of the hollows } \\
\text { resulting from the human activities - the } \\
\text { outer edges of these hollows. } \\
\text { If the natural reservoir or the hollow } \\
\text { created a result of the human activity } \\
\text { crosses the boundary of the cadastral unit, } \\
\text { then the edge of the intersection limits the } \\
\text { contour of the land under the surface still } \\
\text { waters }\end{array}$ \\
\hline
\end{tabular}


It is true that the shoreline of natural watercourses, lakes and other natural reservoirs, as the boundaries of the contour of the land under surface flowing waters was indicated, but in the case of canals or artificial reservoirs situated on the flowing waters, the boundary of this contour are at the outer edges of these canals or reservoirs. Thus, in the Register of land and buildings, defining contours of land under surface flowing waters will be based on the record of the factual circumstances. It is a pity that the legislature did not take into account the suggestions made in the publication by Kowalski and Majewska [3], concerning a need to define a new type of usable land - the land covered by surface flowing waters as a result of an artificial human activity. Then the usable land under the surface flowing waters (Wp) would be reserved only for the land owned by the State Treasury.

\subsection{The Existing Regulations for Determining a Shoreline}

The boundary of real estate under flowing waters shall be determined in accordance with the shoreline. The shoreline of the natural watercourses, lakes and other natural reservoirs is the edge of the shore or the line of permanent grass growth, or the line which is determined by the average level of water from a period of at least the last 10 years (article 15 section 1 ). The basis for adjusting the shoreline is a draft delimitation between the land covered by the waters and the adjacent land, supplied by the applicant.

The shoreline shall be determined by means of a decision, at the request of a person having a legal or factual interest, issued by:

- the competent local maritime administration authority - for internal marine waters and territorial sea waters,

- the competent Marshal of the province - for the boundary waters and inland waterways,

- the competent governor pursuing the task of the government administration - for other waters.

The project of delimitation of the land covered by waters from the adjacent land should include:

- a description taking into account the identification of the applicant, indicating their registered seat and address, the adopted method of determining the proposed shoreline, the determination of the legal status of the real estate covered by the project, with the identified owners including an indication of their registered seat and address, as well as the status of hydrographic conditions on the land adjacent to the proposed shoreline;

- a map of the as-built inventory of regulatory structures, or an updated copy of the base map at a scale in which a draft regulation of inland waters is drawn up, or at a scale of $1: 500,1: 1,000,1: 2,000$ or 1:5,000, demonstrating:

- the fixed points of the horizontal control tied to the national network,

- the line of permanent grass growth,

- the edges of banks, shores, alluvium, fluvial deposits and islands,

- the proposed shoreline. 
The applicant may submit a request to the competent authority for an exemption from the obligation to include in the project some of the above information, if they do not affect the determination of the shoreline.

The method of determining the shoreline is defined in a hierarchical manner. In the case of adjusting the boundaries of a natural watercourse, when the edge of the shore is clear, the shoreline runs along this edge. If the edge of the shore is not clear, the shoreline runs along the line of permanent grass growth, and if the line of permanent grass growth lies above the average water level of the past 10 years - along the line of intersection of the water surface at this level with the adjacent land.

In a situation where the shores of waters are regulated, the shoreline runs along the line connecting the outer edges of the regulatory structures, and by the wicker plantations on the land obtained through regulation - along the boundary of the plantation on the land side.

A decision establishing the shoreline includes the section and the banks of the natural watercourse which are covered by the draft regulation. If the adjustment of the shoreline is necessary in relation to the implementation of water facilities or shaping new natural watercourse beds, the proceedings to determine the shoreline are carried out together with the proceedings to issue a permit required under the Water Act. In the case of changing the shoreline, the decision may be amended in accordance with and subject to the principles relevant to its issuance. If the determination of the shoreline appears necessary as a result of the permanent occupation of the land which does not represent a property of the owner of the water, by flowing waters or marine waters in a natural way, the costs of the project for the delimitation of the land covered by the waters from the adjacent land shall be borne by the owner of the water.

\subsection{Technical Problems Related to the Procedure for Determining the Shoreline}

The publications $[1,2,4,13]$ are dominated by the views that during the development of the draft delimitation of the land covered by waters from the adjacent land, a surveyor, a hydrologist and the authority conducting the administrative proceedings must cooperate. This position is the most appropriate.

The first issue, which is the full responsibility of a surveyor, is to prepare a map containing the development of the draft regulation of inland waters. As indicated above, it is an updated copy of the base map or the map of the as-built inventory of the regulatory structures. Both the performance of the as-built inventory and the updating of the base map are the surveying works which require notification to the cartographic documentation center [8], as well as the land surveyor having the $1^{\text {st }}$ level of certification, specified in article 43 clause 1 of the Surveying and Mapping Law [11]. For this map, the Water Law allows for all the scales of the base map, however, it seems that the scale should be selected in such a way that the draft project is 
readable regardless of the base map existing in a given area. The content of the base map should be kept current. This is particularly important due to the possibility of developments in the areas adjacent to watercourses, as well as due to the fact that the objects which are essential in determining the shoreline, such as a dam, a floodgate or a slope, until the entry into force of the Regulation of 12 February 2013 on the database of geodetic records of public utilities, the databases of topographic objects and the base map [6], were the optional contents of the base map. The measurement of these elements resulted exclusively from the investors' request, it was not mandatory. Therefore, they often do not appear on the base map, even though they exist in the field. In addition, all the elements referred to in article 15 section 3 of the Water Act should be surveyed.

Another problem concerns the accuracy of the carried out measurements and the possible generalization of the surveyed structures. According to the Regulation of 9 November 2011 on the technical standards for performing detailed field measurements as well as the development and transfer of the results of these measurements to the National Cartographic Information Center database [9], the field details such as: building structures and ground structures in the form of embankments, excavations, dikes, dams, levees, ditches, canals and artificial lakes are the $2^{\text {nd }}$ class of field details, and the watercourses and reservoirs with natural shorelines belong to the $3^{\text {rd }}$ of class field details. Pursuant to $\S 29$ section 1 of this Regulation, surveying detailed measurements are performed in a manner that ensures the determination of the position of these details relative to the nearest horizontal geodetic control points with the accuracy not less than 0.30 meters - in the case of the $2^{\text {nd }}$ class field details, and $0.50 \mathrm{~m}$ - in the case of the $3^{\text {rd }}$ class field details. At the same time, these elements may prove important in determining the course of the shoreline, which ultimately will be a boundary of the real estate covered by waters. Boundary points belong to the $1^{\text {st }}$ class of field details, and should be determined with an accuracy of not less than $0.10 \mathrm{~m}$, relative to the nearest horizontal geodetic control points. The surveyor, while preparing a map of the draft delimitation of the land covered by the waters from the adjacent land, should take this fact into account and adapt measurement accuracy to the needs, even though there are no direct requirements in the technical standards applicable in surveying.

The third issue related to the preparation of a map is associated with the marking on this map the land boundaries of the real estate which is subject to the proceedings. Kucharzak and Kowalski [4] believe that, due to the legal consequences of a shoreline, the current base map used in the process should include boundaries of the real estate established by surveying, and their course should be indisputable. The boundary protocols signed by the real estate owners should serve as proofs. Similarly, Bieda and Jasiołek [1] point to the fact that the boundaries of land included into the scope of the study are essential, and also one of the most important, elements of the map in question. Wolny [13] approached the issue slightly differently. In the case where there is no technical data identifying the location of refraction 
points of boundaries of the adjacent land, he allows for the use of graphical data obtained from cadastral maps. If there is a need to include clearly defined real estate boundaries on the base map, it may happen quite often that the surveyor will have to conduct an additional surveying procedure, as the materials available from the National Cartographic Information Center database will not be sufficient. In addition to the longer time required to prepare the map, such an action requires the surveyor to have the $2^{\text {nd }}$ level of certification, referred to in article 43 section 2 of the Geodetic and Cartographic Law [11].

The next question which arises here, concerns the control of the prepared cartographic study by the National Cartographic Information Center, and possibly accepting it to this database. Should this be conducted at this point, when the updated base map is a typical surveying study, as claimed by Kowalski [2], or should it be carried out after the preparation of the draft delimitation, when the proposed shoreline appears based on it in accordance with [1,13], or only after the administrative decision terminating the procedure has been issued?

A very important problem, which is not governed by the provisions of the Water Act is to identify a person substantially responsible for preparing the draft of a shoreline in accordance with article 15 section 3 of the Act - Water Law. The basis for determining the shoreline is a proposal for delimitation of the land covered by waters from the adjacent land, supplied by the applicant. Unfortunately, it has not been specified anywhere who exactly is held responsible for determining that shoreline. According to Kowalski [2], the project must be designed in a systematic way, with a pre-agreed methodology of designing a shoreline. Each of the accepted methods to design the shoreline should be justified by the type of a watercourse, a kind of the bed and the prevailing hydrological conditions there. The conceptual part of adjusting the shoreline and the reasons for it should be performed by a specialist hydrologist who bears substantial responsibility for the preparation of the project. This solution is essentially perfect, but in practice, as in [13] - it is a surveyor who develops the concept of the course of the waters shoreline, subject to the principles laid down in article 15 sections 1, 3-7. Wolny in [13] assumes that in the proceedings regarding a formal determination of the physically existing shoreline, generally there is no need to perform hydrological research on the land which is adjacent to the proposed shoreline. However, the contractor is obliged to agree (accept) this concept with the unit or body managing the water which is the subject of the study, allowing for possible corrections of the graphics. After such arrangements, according to Wolny [13], it is a surveyor who shall prepare a draft project with the course of the designed shoreline marked in red, and prepare documentation to change the data entered into the register of land and buildings and into the land and mortgage registers. These guidelines, however, do not have any legitimacy. In contrast, an essential issue which absolutely ought to be specified in the provisions of the Water Law is identifying a specialist responsible for the development of the project, as well as whether, with whom, and to what extent, they are to be consulted. 
The shoreline project, determined in one way or another, must be prepared in terms of surveying so that it is possible to determine the boundary of a real estate covered by water with the required accuracy. The Act - Water Law does not specify whether the shoreline should be identified and presented to the parties in the field or if the document prepared in the office is enough. Due to the fact that, in the case of water flowing in a natural riverbed, a change in the course of the shoreline changes the scope of property rights, it seems to be essential. In addition, it is necessary to point to the fact that changes to the course of a determined shoreline may be introduced only by way of the same administrative procedure to amend the previously issued administrative decision. Therefore, it is worth making an effort for the parties to fully accept the shoreline which was determined.

The Water Law mentions the delimitation of land covered by waters and the adjacent land. However, in practice and in the literature [1, 2, 13], a change to the course of the shoreline is carried out by parcelling out a separate plot of land, which is then merged with the plot covered by waters. From a practical point of view this procedure is more obvious - the surveyor (this time with the $2^{\text {nd }}$ level of certification) parcels out the area occupied by water and only prepares documents for the plot of land subject to the proceedings, however, it is in contradiction to the content of the Water Act.

If the law says about the delimitation, the procedure should involve determining a change to the course of the boundaries of the land covered by water, and not the real estate subdivision. This applies both to the proceedings in the field and to the documentation being prepared. From a technical point of view, there are no problems to determine a change to the area of the real estate concerned. There are no problems with a transfer of a parcelled out plot to the water resource database and with merging it with the land occupied by water.

The documentation prepared by an authorized surveyor forms the basis for changes in property rights to the real estate subject to delimitation. It should be drawn up in accordance with the applicable regulations on surveying and cartography, and accepted into the National Cartographic Information Center database. In most proceedings with the active participation of surveyors, basic trig data is accepted into the database before issuing an administrative decision.

\section{The Proposed Complements to the Existing Legislation}

The correct designation of watercourse shorelines is of great significance. The only possibility of its determination is to carry out the procedure for delimitation of the land covered by waters and the adjacent land under the provisions of the Water Act. Unfortunately, due to the too general regulations, it is unclear how to implement this procedure. It is necessary to issue the implementing regulations and to particularize the procedure laid down in the Water Law (Fig. 1). 


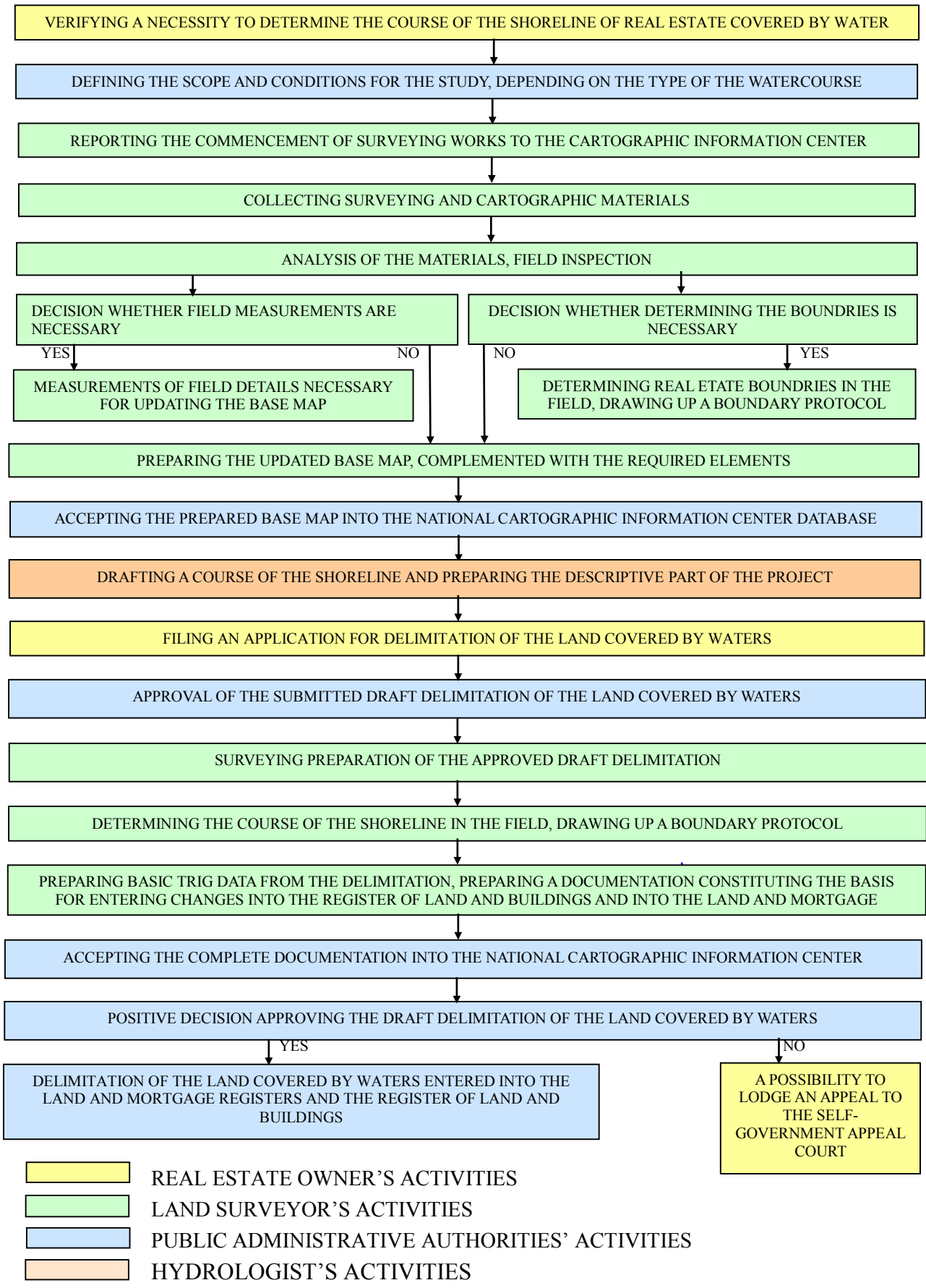

Fig. 1. The proposed procedure for determining the shoreline under the Act - Water Law 
Under the proposed procedure shown in Figure 1, an active part in the implementation of this process is taken by: the applicant, the authorized surveyor with the $1^{\text {st }}$ and $2^{\text {nd }}$ level of certification, the hydrologist, the water manager and the competent administrative authority. From the point of view of the surveyor, it is important to clarify the scope, accuracy and the mode of preparing the map constituting the basis for the drafting of delimitation of the land covered by waters and the adjacent land, as well as the subsequent drafting of the shoreline by surveying. Therefore, the proposed procedure included the arrangements with the water manager regarding the scope and the content of the map. The boundaries of the real estate subject to the proceedings should be clearly established, at least at the section where the shoreline will be drafted. If the register of land and buildings contains data allowing for their determination in accordance with the required standards $(0.30 \mathrm{~m}$ in relation to the first-order national control), they can be used. Otherwise, it is necessary to establish the boundary in the field on the basis of updating the register of land and buildings. The prepared map complemented with the data together with the information required by the provisions of article 15 section 3 of the Water Act should be accepted into the National Cartographic Information Center database before drafting a shoreline on it. The project itself should be developed by the hydrologist, which should be clear from the content of the Water Act. The land surveyor is not substantially prepared for this type of work.

In this procedure, the surveying work consists of two stages mentioned above. The second stage concerns the surveying development of the project accepted by the administrative body. The administrative procedure proposes compulsory proceedings in the field that will result in a boundary protocol describing the newly established boundary line between the land covered by waters and the adjacent land. After the final course of the shoreline has been accepted by the administrative body, a complete basic trig data should be inspected by the district cartographic information center, and then accepted into the national resource database. On the basis of the documentation accepted into the resource, the competent administrative authority shall issue a decision on determining the shoreline - and not on the parcelling out of a part of the real estate naturally occupied by the flowing water.

\section{Summary}

As it was mentioned above, the determination of a shoreline is possible exclusively in the manner provided for in the Act - Water Law [12]. The provisions of the amended regulation on the register of land and buildings [7] allow to identify in the land records the course of the boundary between the land forming the beds and banks of watercourses, lakes and reservoirs and the land adjacent to them, on the basis of the results of the field detailed measurements, the execution of which results in the identification of the course of this boundary, pursuant to the provisions 
of article 15 section 1, 5 and 6 of the Water Act. However, a boundary determined in that way has no legal validity. The procedure for determining the shoreline contained in the Water Law is incomplete and insufficient for its smooth and uniform implementation throughout the country. The presented above procedure for the implementation of the process of determining a shoreline may constitute a basis for complementing the existing regulations.

\section{References}

[1] Bieda A., Jasiołek J.: Linia brzegowa. Nowa Geodezja w Praktyce, nr 1, 2012, pp. 52-56.

[2] Kowalski K.: Gospodarka nieruchomościami pokrytymi powierzchniowymi wodami ptynacymi. Wrocław 2012, [on-line:] www.gruntiwoda.pl [accessed: 1.04.2014].

[3] Kowalski K., Majewska A: Nowy użytek? Powierzchniowe wody ptynace w ewidencji gruntów. Magazyn Geoinformacyjny Geodeta, nr 1(176), 2010, pp. 24-28.

[4] Kucharzak S., Kowalski K.: Geodezyjny aspekt ustalania linii brzegu. Gospodarka Wodna, nr 9, 2009, pp. 357-363.

[5] Rakoczy B.: Prawo wodne. Komentarz. Wolters Kluwer, Warszawa 2013.

[6] Rozporzadzenie Ministra Administracji i Cyfryzacji z dnia 12 lutego 2013 r. w sprawie bazy danych geodezyjnej ewidencji sieci uzbrojenia terenu, bazy danych obiektów topograficznych oraz mapy zasadniczej. Dz.U. 2013, poz. 383.

[7] Rozporzadzenie Ministra Rozwoju Regionalnego i Budownictwa z dnia 29 marca 2001 r. w sprawie ewidencji gruntów i budynków. Dz.U. 2001 nr 38, poz. 454, Dz.U. 2013, poz. 1551.

[8] Rozporzadzenie Ministra Rozwoju Regionalnego i Budownictwa z dnia 16 lipca $2001 \mathrm{r}$. w sprawie zgłaszania prac geodezyjnych $i$ kartograficznych, ewidencjonowania systemów i przechowywania kopii zabezpieczajacych bazy danych, a także ogólnych warunków umów o udostępnianie tych baz. Dz.U. 2001 nr 78, poz. 837.

[9] Rozporzadzenie Ministra Spraw Wewnętrznych i Administracji z dnia 9 listopada 2011 r. w sprawie standardów technicznych wykonywania geodezyjnych pomiarów sytuacyjnych $i$ wysokościowych oraz opracowywania i przekazywania wyników tych pomiarów do państwowego zasobu geodezyjnego i kartograficznego. Dz.U. $2011 \mathrm{nr} 263$, poz. 1572.

[10] Ustawa z dnia 23 kwietnia 1964 r. Kodeks cywilny. Dz.U. 2014, poz. 121.

[11] Ustawa $z$ dnia 17 maja 1989 r. Prawo geodezyjne i kartograficzne. Dz.U. 2010 nr 193, poz. 1287 with amendments. 
[12] Ustawa z dnia 18 lipca 2001 r. Prawo wodne. Dz.U. 2012, poz. 145 with amendments.

[13] Wolny B.: Sporzadzanie geodezyjnej dokumentacji projektowej linii brzegu morskich wód wewnętrznych oraz śródladowych wód powierzchniowych. Przegląd Geodezyjny, nr 4, 2008, pp. 15-22.

[14] Źróbek S., Źróbek R., Kuryj J.: Gospodarka nieruchomościami z komentarzem do wybranych procedur. Wydawnictwo Gall, Katowice 2006. 